\title{
Couples and shared leisure experiences
}

By: Justin Harmon

Harmon, J. (2016). Couples and shared leisure experiences. World Leisure Journal, 58(4), 245254. doi: 10.1080/16078055.2016.1225883

This is an Accepted Manuscript of an article published by Taylor \& Francis in World Leisure Journal on August 31, 2016, available online: http://www.tandfonline.com/10.1080/16078055.2016.1225883.

***@) Taylor \& Francis. Reprinted with permission. No further reproduction is authorized without written permission from Taylor \& Francis. This version of the document is not the version of record. Figures and/or pictures may be missing from this format of the document. $* * *$

\section{Abstract:}

This paper explored how romantic couples' involvement in a music scene affected both individual and mutual enjoyment during participation which stimulated the desire for future shared leisure experiences. As all aspects of involvement were seen as largely positive, shared music scene participation served as a vehicle to grow together and strengthen relationships. Through joint participation couples were able to affect their collective well-being in three ways: (1) participation on an individual level led to accrued happiness through lengthy and frequent involvement in an activity that was significantly meaningful and a high priority in each participant's life; (2) participation and interaction with their significant other in the activity that had high value for both led to shared happiness and (3) the shared participation led to greater well-being for the union of the partnership through the existence of mutual friendships, meaningful music and positive experiences of release, recharging and catharsis.

Keywords: Leisure | positive psychology | music | couples | shared experiences

\section{Article:}

As usual, Jerry Joseph \& the Jackmormons played their annual run of New Year's shows in Portland, Oregon in the final days of December, 2014. What made this rendition all the more special were two events: The first was the wedding ceremony of Scotty and Kristin on December 30th before the first installment of a four night concert series. Scotty and Kristin had gotten engaged at another string of Jackmormons' concerts that past August. The second was a proposal and engagement from the stage on December 31st from Matt to Molly. Matt and Molly had met at a Jackmormons' concert two years earlier. The reasonsfor both couples to choose to have these monumental life events take place at a rock $\mathrm{n}$ roll show was based on their shared, and lengthy, involvement in the music scene surrounding the band Jerry Joseph \& the Jackmormons. The music had been so important to their lives as individuals, and now as couples, that the forum was the only appropriate place for these public displays of affection and commitment to take place. The fact that they had all made numerous close friends through the conduit of their participation 
in the music scene guaranteed that they would have a collection of special people to help share in the happiness of the celebration.

\section{Introduction}

For many people, finding that special someone to share their lives with is at the root of happiness (Swidler, 2003). While one can be fulfilled socially, intellectually and professionally, some people will not be fully satisfied until they find the person who makes them feel complete. As are many things in life, dating and finding romantic partners is often rife with trial-and-error. There are many unsuccessful interactions as we attempt to navigate ourselves through the maze of the dating world (McIntosh, Locker, Briley, Ryan, \& Scott, 2011). Once we find that perfect match, however, it can change our outlook on life and reinvigorate us as if we have found the key to happiness. But just as important as finding that special someone is having meaningful moments to share with them. Shared interests or activities that are both engaging and rewarding are often integral to the success of a couple (Kalmijn \& Bernasco, 2001). So when there is an outlet or activity that is equally compelling to both partners, it follows that the potential for shared experiences may serve as the "connective tissue" that holds and binds the couple together.

This investigation explored couples' shared leisure experiences in the context of the music scene of the rock band Jerry Joseph \& the Jackmormons. When people share music preferences it tends to intensify the connection to one another (Boer et al., 2011). Further, music can also help to create psychological connections to loved ones (Laiho, 2004). When couples are able to use meaningful, shared leisure activities like music scene participation as a means to connect and build their relationship, it follows there will be greater satisfaction in the relationship (Baldwin, Ellis, \& Baldwin, 1999) and higher levels of mutual well-being (Flora \& Segrin, 1998). What this study sought to surmise was, how do couples' shared leisure experiences lead to greater happiness and well-being for the relationship?

\section{Literature review}

\section{Shared leisure}

When couples develop a joint lifestyle through shared leisure activities they "produce a set of goods" that are connected to their union and benefit the stability and happiness of their relationship (Kalmijn \& Bernasco, 2001, p. 639). Orthner and Mancini (1990) developed a framework for the examination of couples and their leisure. The framework consisted of three patterns of involvement: individual, parallel and joint leisure. Individual leisure refers to leisure done without one's partner or spouse. Parallel couple leisure involves both partners participating at the same time, but not necessarily interacting or communicating. Watching television or reading in the same room are expedient examples. Joint couple leisure is composed of couples participating in leisure that requires a high level of mutual engagement, such as rowing a boat or performing music together.

And while Orthner and Mancini (1990) drew clear distinctions between their definitions of parallel and joint couple leisure, it is my assertion that there are leisure activities that not only foster both patterns, but actually produce a better shared experience for couples when both elements are invoked. To the best of my knowledge, this co-existence of joint and parallel interactions in a leisure activity has not been explored. As will be displayed, the couples who 
participated in this study looked forward to and embraced their shared leisure involvement, but also used the music scene as a forum to strengthen other friendships and attend to their personal happiness as well. As indicated by Sharaievska, Kim, and Stodolska (2013), in order to promote marital satisfaction, and therefore shared happiness, "couples should strive for a balance between joint and individual leisure that is optimal for both spouses" (p. 458). While I agree with this declaration, the context of this study has both partners participating together, and in parallel, in the same activity making the dynamic of joint/parallel couple leisure the topic for exploration as opposed to the balance of individual/joint couple leisure.

Positive psychology

Positive psychology attempts to understand the intersection of valuable experiences from the past, present and future as a way to help people live happy lives. Satisfaction from past experiences can lead to happiness in the present and hope and optimism for the future (Seligman \& Csikszentmihalyi, 2000). The positive emotions that are generated from our experiences can lead to individual growth and social bonding by building individual and communal resources that "transform people for the better, giving them better lives in the future" (Fredrickson, 2001, p. 224). When these positive experiences are shared with a loved one, such as a romantic partner, it can lead to the creation of "mutual enjoyment in the moment" and "enduring alliances" that individuals draw on in later times of need (Fredrickson, 1998, p. 311).

Steger (2011) said that the essence of meaning in life is in the connections we make. What people live their lives for is to strive for a purpose for existence beyond the ephemeral moment. When people find passionate leisure activities that captivate their individual desires and capabilities, and are able to share them with someone they love who holds those same sentiments, it leads to shared meanings that become their reality (Kyle \& Chick, 2002). By finding positive meaning through a shared leisure activity it broadens thought processes and increases the likelihood of reinforcing positive meanings in future iterations of involvement (Fredrickson, 2001). As will be displayed in this paper, the couples participating in the music scene engaged in multiple interactions with the music, themselves, their friends and, perhaps most importantly, their significant other.

\section{Methods}

\section{Study participants}

Data were generated from in-depth, semi-structured interviews with 16 participants (8 couples) between July 2013 and April 2015. Participants were chosen through purposive sampling (Patton, 1990) based on the author's knowledge of fan involvement in the music scene. Five of the couples were interviewed together with three being interviewed separately. The decision on whether or not to interview the couples together was left up to each pair or based on availability. At time of interview the youngest participant was 29 and the oldest was 58, with a mean age of 44 years. All participants had been attending the band's performances for at least five years, with several having seen the band perform live for a decade or more. Most fans attended more than 10 shows a year. All fans were assigned pseudonyms to protect their identity, but if others from the fan community were to read the manuscript they may be able to surmise identity based on the closeness and small size of the subculture. 
In-depth interviews

A list of open-ended questions were created to serve as a template for interviews. I encouraged fans to elaborate on their personal meanings and shared experiences of involvement in the music scene. I was particularly interested in how the couples used the music outside of the concert setting, how they interacted together at concerts and what special moments they shared at shows that were of great importance to their personal and collective wellbeing. All interviews were recorded with permission of the participants and notes were taken during the interview to document emotions or affect unable to be captured by audio. Interviews with individuals lasted for at least one hour, and individuals with couples lasted for at least two hours. Some of the questions asked included: How does your involvement in the music scene affect your life? How would you describe the friends you have made through your involvement? And, does the music affect your relationship with your spouse/partner in any way?

Data analysis and interpretation

The foundation of data analysis was grounded theory as demonstrated by Charmaz (2006). An understanding of individual and couples' meanings was reached through an inductive process that considered how each participant expressed and interpreted their involvement and how their shared participation affected their relationship. The analysis process involved the use of primary and secondary coding (Tracy, 2013) as well as several thorough readings of interview transcripts. Primary codes were assigned, when possible, using in vivo terminology (the actual words of the participants). Data were managed by establishing a hierarchy of relevance to the study's purpose and research question (Saldaña, 2012). Once categories were created themes emerged and served as the foundation for the paper about how couples' shared leisure experiences led to greater individual and collective well-being. The findings will be discussed in three themes: individual involvement and attraction to the music; mutual friendships made in the music scene and couples' shared experiences of involvement in the music scene.

\section{Results and discussion}

Individual connections

I really feel as if I was once "in love" with the music [of Jerry Joseph]. Obsessed is perhaps the better description, but it felt like [being] in love at times. Like the music gave me solace ... like it was a blanket that cloaked me with a peaceful feeling that was desperately needed at times. His music gave me what no human could at times in my life. I don't know. I suppose a person cannot be in love with something that does not breathe, but music does seem to have a heartbeat and a mind of its own at times. (Kelly)

All of the fans I spoke with had long personal histories with music in their lives. For many, music acted as a friend when there was no one around to serve that role (Saarikallio \& Erkkilä, 2007). As the participants aged, they continued to use music in their lives for establishing identity, meaning making and developing friendships based on mutual taste and interests (Schäfer \& Sedlmeier, 2009). The reflexive process of remembering and constructing their identities often came through their personal associations to music (DeNora, 2000). So when the 
participants found the music of Jerry Joseph \& the Jackmormons, they felt as if they found something that spoke to them personally and was a source for introspection, release and catharsis. Becky had this to say about her personal connection to the music when at a Jackmormons' concert:

It's a time when the only thing that's important is being there and being with the music. There's absolutely nothing else. There's not a to-do list. My focus is $100 \%$ on the music. The only time in my life when I'm like that is when I'm at a Jerry Joseph show. His music is as much a part of me as food and oxygen. It's a necessity.

For Becky, and others, their personal involvement at a Jackmormons' concert was a place where they could be themselves and focus on being in the moment. Their participation was a conduit to achieving happiness through the music; not only during the concert, but into the future as well. This is in tune with Fredrickson's (1998) broaden-and-build theory in that the experience of positive emotions can be a "durable personal resource that can be drawn on later in other contexts and emotional states" (p. 307). This was evidenced by a statement from Kurt: "After the shows, I'll be able to store positive energy for weeks, months, maybe even years. You're creating memories and stories you can tell, and most importantly, you're doing it with the people you love."

As evidenced by Becky and Kurt's statements, many fans felt their lengthy and extensive involvement in the music scene of the Jackmormons was of utmost importance to their lives. When I asked Bill for closing thoughts at the end of our interview, he had this to say:

I would say that this is so important to me that one of the things in my life that frightens me the most is if this goes away. And I know it will. We'll all die someday. I'll lose you or you'll lose me (to his wife, Viv). It's almost at that level. That's one of the things that frightens me about the future.

His wife Viv added: "It's so important to us. We've made so many friends. We wonder what will happen when we no longer have the band." As Ruud (1997) stated, music, for the participants of this study, was a source of personal discovery that allowed narratives to be constructed for how each individual perceived what they wanted their lives to be like. Fan involvement affected their quality of life for the better through the ability to engage in experiences that made them happy and led to a sense of well-being from their connection to the music.

Mutual friendships

[Kristin reflecting on her participation at the Jackmormons' Dixie Mattress Festival]: It was so much fun. It's just so easy to fit in with this group for me. I was apprehensive at first because I'm new to the scene (she only became intricately involved once she met her now husband), but I've been embraced fully and openly. Kevin, Scotty's (her husband) best friend, was rightfully apprehensive when we got engaged at Virginia City after only dating for two months, but [Kevin and I] have developed a great relationship since. When all the commotion leading up to the week took place and we had to shell out extra money because we lost the house on the beach when the festival moved, I was thinking about not going because I couldn't afford to and I didn't want Scotty to have to spend more money 
on me. But Kevin stepped up and said I was going and that we'd alter our travel plans so that everything would work out for me. He showed so much love because he wanted me to have this experience. That made the weekend which was already so great that much better. Knowing that someone cared enough and wanted me there, it was real. I was willing to not go so they could have fun, but he wasn't having it. He wanted me there. He wanted Scotty and me to experience Dixie together.

Much as music can be integral to shaping personal identity, it also possesses the ability to shape social identity as well (Lonsdale \& North, 2009). When people are engaged in life and secure in their social networks, the binding of their social and personal identities can lead to high selfesteem which results in happiness for the future based on satisfaction with one's current state in life (Hewitt, 2011). Lloyd and Auld (2002) said that "the objective measure of social leisure participation", such as going to concerts with friends and one's significant other, is "the best predictor of quality of life" (p. 63). That couples are able to not only enjoy the leisure experience, but also that of a shared pool of friends, that can lead to a stronger relationship in the long run (Johnson, Zabriskie, \& Hill, 2006).

For the participants of this study, the multiple shared friendships that the couples had added to the overall experience of participation in the music scene. In fact, most participants considered many of their friends to be "family" and frequently used the term to refer to their fellow fans (Harmon \& Kyle, 2016). When asked about they would describe the fan base, Mallory had this to say:

This is our family. When you have people you love so dearly and would do anything for them, and accept their good and bad aspects, and tolerate things they do that you wouldn't from others, [it is] because you just love them. You get on that dance floor and share a glance and can tell how happy they are; you and me, we're right here together.

I asked Kurt the same question and he stated that the fan base was:

Unlike any other. There's no fake angles to it. A lot of that is due to maturity. We're not here to impress anybody, we love each other, and we're going to treat each other as we want to be treated. I think people are a little more comfortable with themselves. If I hit a major hardship, they may not jump on a plane and come see me, but I think I could feel their presence, their blessings, [and] their prayers per se. When you sense that people truly care about you, it's sincere. I wish my real family was more like my family of friends [in the Jackmormons' scene].

Here we see both Mallory and Kurt speaking about the strength of the friendships they made through their participation in the music scene. And while they both invoked themes of "love" and "family" to describe the connections, elements that are typically ascribed to significant others or literal families, by doing so they acknowledged a larger social support network that allowed them to feel comfortable in the confines of the music scene. All participants of this study echoed these sentiments by stating or implying that their involvement was not solely tied to their spouse or partner. In fact, the ability to feel safe in the environment of the concert setting with a large collection of shared friendships lent comfort and opportunities for personal development through participation that served to strengthen the bonds of their respective relationships. Because 
involvement in the Jackmormons' subculture invoked both a joint and a parallel element of participation, these data discount the claim that parallel leisure may "provide less benefit to couples" (Johnson et al., 2006). As the parallel couple leisure activities occur in the same window of time as the joint couple leisure, it may be an area for further investigation about how couples can break up their leisure time to receive a more well-rounded experience.

Couples' shared leisure

[Julia talking about her favorite Jackmormons' concert]:

May 11th, 2005. I love that show. I flew out to Atlanta and stayed with friends. After the show was over Thursday, I'd never met Kurt before, and I yelled that I needed a ride to Nashville. A guy raised his hand and I went over and talked to him and got his number. I asked my friends about him and they indicated that Kurt was a good guy. He drove over the next day and picked me up, and as we're driving to Nashville we're talking and laughing, and he says, how far are you from Lyons, CO? That's actually where I lived at the time. I said "Why?" He said he had to go to a wedding up there. I said, "Matt \& Nicky's wedding?" He said "Yes." We had common friends, which was odd. It turned out we were driving to the same house in Nashville when it came time to drop me off. I got Kurt to go to the Jackmormons' show in Nashville that night; he blew off his other plans, it was great. They played [the songs] "Whatever's in the Basket", and "Dear Prudence", and Kurt and I fell in love at that show. He ended up taking me back to Atlanta and going to my friends' house for a BBQ with me, and the rest is history.

Nearly three-quarters of a century ago, Locke (1951) said that couples who agree on leisure activities and the value of spending quality time together tend to be happier. When couples spend more of their leisure time together it often means that the relationship has become more intimate and the value of shared experiences are integral to sustaining that connection (Voorpostel, van der Lippe, \& Gershuny, 2010). It is through these shared leisure experiences that couples create mutual enjoyment in the moment that are vital to enduring alliances and seek to serve the stability of the relationship for the future (Fredrickson, 1998).

As indicated in the opening vignette, two sets of couples from this study got engaged while at a Jackmormons' concert. The reason to do so has an historical element due to each individuals' personal timeline of involvement and connection to the music as well as the friendships that were crafted during their deeper immersion into the subculture. The paramount reason to make these lifelong commitments in the forum of a Jackmormons' show was because their involvement as couples had been, and continues to be, of high importance to their personal, social and, most significantly, romantic identities. Put simply, without their involvement in the music scene, Matt and Molly may have never met, and Scotty and Kristin would not have been able to share unique experiences in areas they both found very captivating and romantic.

While speaking with Scotty and Kristin I asked Scotty if there was a symbolic element to their participation, especially since they had gotten engaged and married at Jackmormons' events. Scotty glanced over to the fireplace mantel at the drumhead that had been signed and given to them by the band the night they got married. He said:

We wanted Mickey and Mallory and Emily and Dan to be part of it (they all live closer to Portland, OR where the shows were).We knew all these people we wanted to be there 
that would be at the New Year's shows. The band plays a big part. She'd [Kristin] never been to Montana (where they had gotten engaged in August, 2014) and wanted to go. I woke up that first day and she was so happy I was going to propose to her while we were there. When we walked into the show that night after we got engaged, Big Mike was standing up front and goes, "Did you hear about the guy who got drunk and proposed to his girlfriend?!?” And I said, "Right here, man!" (Laughs) Walking in, Kevin had already spread the word. I had been around [the music scene] for a while, people knew me. But for her, she got wrapped up in this family in a good way right off the bat.

The ability to share meaningful leisure provided many layers for each couple. In addition to serving as a forum to profess love publically and become engulfed in the communal feeling, the music scene was also a place where couples could be intimate in a less prominent manner. While speaking with Mickey and Mallory, I asked them if they viewed their participation as a method of escape. Mallory quickly responded that it was "therapy". Mickey said that it was "couples counseling". Mickey then followed up that assertion with this statement: "I can't imagine how we would get through it without one another. We've both only seen one show without one another." Here we see that receiving emotional support in the context of their leisure participation plays an important role in maintaining high levels of happiness for the couple (Baldwin et al., 1999). The ability to share intimate moments with one another in their leisure, for all of the couples who participated in this study, was integral to their satisfaction in their moments of participation, as well as into their broader lives outside of the music scene (Ward, Barney, Lundberg, \& Zabriskie, 2014). As experiences of love are made up of many positive emotions, including interests and happiness, the immersive leisure interactions that fuel that love then also possess the ability to strengthen the foundations of the connection (Fredrickson, 1998).

\section{Conclusions}

As evidenced by the participants of this study, Orthner and Mancini's (1990) framework of couples' leisure should be expanded to consider how certain leisure activities can fill multiple parts of their concept. Specifically in this study it was displayed that a specific leisure activity contains both joint and couple leisure offerings. It could in fact be stated that in the context of this music scene that all three could transpire. Throughout the interviews each participant stated how they had participated in the music scene of Jerry Joseph \& the Jackmormons in some way without their significant other. This was typically through attending concerts with other fan friends in the absence of their spouse or partner. And while Orthner and Mancini's review of literature found that activities engaged in on an individual basis often had a negative influence on romantic relationships, I would argue just the opposite. Because each partner understood the importance of the music for each other they all agreed it was perfectly acceptable for one another to participate alone or with friends, especially if one spouse was unable to for some reason. In fact, it was encouraged as a loving gesture. It was through the, admittedly few, interactions in the music scene on an individual level where one partner was able to store positive emotions from their involvement and bring those sensations to the relationship which then aided in strengthening it through the reciprocal exchange of understanding and love for the experience (Fredrickson, 2001). It was, of course, preferred by all couples to interact in the music scene together, and it was often the norm that there existed a joint and a parallel component. 
Shared leisure experiences for couples allow for the building of "marital capital" (Kalmijn \& Bernasco, 2001, p. 639) in avenues that are comfortable and result in quality time together (Johnson et al., 2006). When there is open commitment and support for one another's leisure preferences, there will be greater satisfaction in the union (Baldwin et al., 1999). And while this study found that parallel couple leisure experiences can be just as rewarding to the health of the relationship, joint couple leisure experiences are at minimum the other side of the coin of a happy union. When couples share interests in their leisure choices, and engage in them together, the relationship will be stronger (Sharaievska et al., 2013) and the potential for personal and collective well-being will be greater.

\section{Disclosure statement}

No potential conflict of interest was reported by the authors.

\section{References}

Baldwin, J. H., Ellis, G. D., \& Baldwin, B. M. (1999). Marital satisfaction: An examination of its relationship to spouse support and congruence of commitment among runners. Leisure Sciences, 21, 117-131.

Boer, D., Fischer, R., Strack, M., Bond, M. H., Lo, E., \& Lam, J. (2011). How shared preferences in music create bonds between people: Values as the missing link. Personality and Social Psychology Bulletin, 37(9), 1159-1171.

Charmaz, K. (2006). Constructing grounded theory: A practical guide through qualitative analysis. Thousand Oaks, CA: Sage.

DeNora, T. (2000). Music in everyday life. Cambridge: Cambridge University Press.

Flora, J., \& Segrin, C. (1998). Joint leisure time in friend and romantic relationships: The role of activity type, social skills and positivity. Journal of Social and Personal Relationships, 15(5), 711-718.

Fredrickson, B. L. (1998). What good are positive emotions? Review of General Psychology, 2(3), 300-319.

Fredrickson, B. L. (2001). The role of positive emotions in positive psychology: The broadenandbuild theory of positive emotions. American Psychologist, 56(3), 218-226.

Harmon, J., \& Kyle, G. T. (2016). Community, family and leisure immersion. Leisure/Loisir, 40(1), 79-100.

Hewitt, J. P. (2011). The social construction of self-esteem. In S. J. Lopez \& C. R. Snyder (Eds.), The Oxford handbook of positive psychology (2nd ed., pp. 217-224). Oxford: Oxford University Press.

Johnson, H. A., Zabriskie, R. A., \& Hill, B. (2006). The contribution of couple leisure involvement, leisure time, and leisure satisfaction to marital satisfaction. Marriage \& Family Review, 40(1), 69-90.

Kalmijn, M., \& Bernasco, W. (2001). Joint and separated lifestyles in couple relationships. Journal of Marriage and Family, 63, 639-654.

Kyle, G., \& Chick, G. (2002). The social nature of leisure involvement. Journal of Leisure Research, 34(4), 426-448.

Laiho, S. (2004). The psychological functions of music in adolescence. Nordic Journal of Music Therapy, 13(1), 47-63. 
Lloyd, K. M., \& Auld, C. J. (2002). The role of leisure in determining quality of life: Issues of content and measurement. Social Indicators Research, 57(1), 43-71.

Locke, H. J. (1951). Predicting adjustment in marriage: A comparison of a divorced and a happily married group. New York, NY: Holt, Rinehart \& Winston.

Lonsdale, A. J., \& North, A. C. (2009). Musical taste and ingroup favoritism. Group Processes \& Intergroup Relations, 12(3), 319-327.

McIntosh, W. D., Locker Jr., L., Briley, K., Ryan, R., \& Scott, A. J. (2011). What do older adults seek in their potential romantic partners? Evidence from online personal ads. International Journal on Aging and Human Development, 72(1), 67-82.

Orthner, D. K., \& Mancini, J. A. (1990). Leisure impacts on family interaction and cohesion. Journal of Leisure Research, 22(2), 125-137.

Patton, M. (1990). Qualitative evaluation and research methods. Newbury Park, CA: Sage.

Ruud, E. (1997). Music and the quality of life. Nordic Journal of Music Therapy, 6(2), 86-97.

Saarikallio, S., \& Erkkilä, J. (2007). The role of music in adolescents' mood regulation. Psychology of Music, 35(1), 88-109.

Saldaña, J. (2012). The coding manual for qualitative researchers. Thousand Oaks, CA: Sage.

Schäfer, T., \& Sedlmeier, P. (2009). From the functions of music to music preference. Psychology of Music, 37(3), 279-300.

Seligman, M. E. P., \& Csikszentmihalyi, M. (2000). Positive psychology: An introduction. American Psychologist, 55(1), 5-14.

Sharaievska, I., Kim, J., \& Stodolska, M. (2013). Leisure and marital satisfaction in intercultural marriages. Journal of Leisure Research, 45(4), 445-465.

Steger, M. F. (2011). Meaning in life. In S. J. Lopez \& C. R. Snyder (Eds.), The Oxford handbook of positive psychology (2nd ed., pp. 679-688). Oxford: Oxford University Press.

Swidler, A. (2003). Talk of love: How culture matters. Chicago, IL: University of Chicago Press. Tracy, S. (2013). Qualitative research methods: Collecting evidence, crafting analysis, communicating impact. Hoboken, NJ: Wiley-Blackwell.

Voorpostel, M., van der Lippe, T., \& Gershuny, J. (2010). Spending time together - changes over four decades in leisure time spent with spouse. Journal of Leisure Research, 42(2), 243-265.

Ward, P. J., Barney, K. W., Lundberg, N. R., \& Zabriskie, R. B. (2014). A critical examination of couple leisure and the application of the core and balance model. Journal of Leisure Research, 46(5), 593-611. 